\title{
A NEW OLIVERIANA (ORCHIDACEAE: ONCIDIINAE) FROM ECUADOR
}

\author{
STIG DALSTRÖM \\ 2304 Ringling Boulevard, unit 119, Sarasota FL 34237, U.S.A. \\ Lankester Botanical Garden, University of Costa Rica, Cartago, Costa Rica \\ The National Biodiversity Centre, Serbithang, Bhutan \\ stigdalstrom@gmail.com
}

\begin{abstract}
A new species of Oliveriana is described and illustrated. It is compared with and distinguished from all other listed members of the genus by a unique combination of distinct features, such as the extremely elongate and narrow leaves, and a flower with a fleshy triangular lip. It is speculated here that this new species may be self-pollinating due to the high success of seed pod production, which is unusual among genera in Oncidiinae.
\end{abstract}

KEY words: Ecuador, new species, Oliveriana, Oncidiinae, Orchidaceae

Introduction. The genus Oliveriana Rchb.f. was described in 1877, according to the title page of the publication of Linnaea where the description occurs, but was actually published in December 1876 according to Moore and Wood (1965). It was based on the description of Oliveriana egregia Rchb.f. (Reichenbach 1876). The type plant was originally collected by Gustav Wallis who provided a dried inflorescence carrying six flowers to Reichenbach in Hamburg. The type specimen appears to have been collected somewhere near Medellín in Colombia like so many others of Wallis' collections. A drawing of what appears to represent the holotype can be seen in Xenia Orchidacea (Reichenbach 1883: 63, pl. 230; figs. 1-4) (Fig. 1).

Reichenbach placed Oliveriana egregia somewhere between Bifrenaria Lindl., and Stenocoryne Lindl., in the original description (the latter genus currently considered to be part of Bifrenaria as well, according to the World Checklist of Selected Plant Families). Oliveriana egregia has also been considered to belong to Trichopilia Lindl., by Bentham (1881). Leslie Garay disagreed with Bentham and placed Oliveriana egregia "in the Tribe Oncidiae" (Garay 1963). Recent molecular evidence shows that Oliveriana indeed belongs to Oncidiinae (Chase et al. 2009), as a sister clade to Systeloglossum Schltr., and they together form a sister clade to Cischweinfia Dressler \& N.H. Williams (Chase et al. 2009). The plant and flower morphologies of Oliveriana and Systeloglossum are very similar and the genera are basically separated only by the presence of a columnar mentum for Systeloglossum species, while flowers of Oliveriana generally lack a distinct chin. Since Systeloglossum costaricense Schltr. lacks a distinct mentum, and Oliveriana brevilabia (C.Schweinf.) Dressler \& N.H.Williams does display a short but distinct chin, the separating definition for these genera breaks down, and this has led authors to mention that the two genera can be merged (Dressler \& Williams 1970, Chase et al. 2009). The morphological similarities between members of the Oliveriana-Systeloglossum clade versus members of Cischweinfia is less convincing, however, which supports maintaining these clades as separate genera.

For almost a century Oliveriana was a monotypic and apparently very little known genus, with O. egregia as its only species. Leslie Garay (1963) then described Oliveriana lehmannii Garay from Colombia, which he believed was a second species. There was already a second species described, however, but hiding under the name of Odontoglossum brevilabium C.Schweinf. (Schweinfurth 1949). It was transferred to Oliveriana by Robert Dressler and Norris Williams (1970). One year before this transfer Pérez (1969) described another Colombian species as Oliveriana ortizii A.Fernández, followed two decades later by Oliveriana ecuadorensis Dodson (1989) from Ecuador, and Oliveriana simulans Dodson \& R.Vásquez (1989) from Bolivia. Then in 2014 six more species were added to the genus. They were Oliveriana guariniae Szlach., Kolan. \& Oledrz., O. pseudoegregia Szlach., Kolan. \& Oledrz., and O. puracensis Szlach., Kolan. \& Oledrz. (Szlachetko 


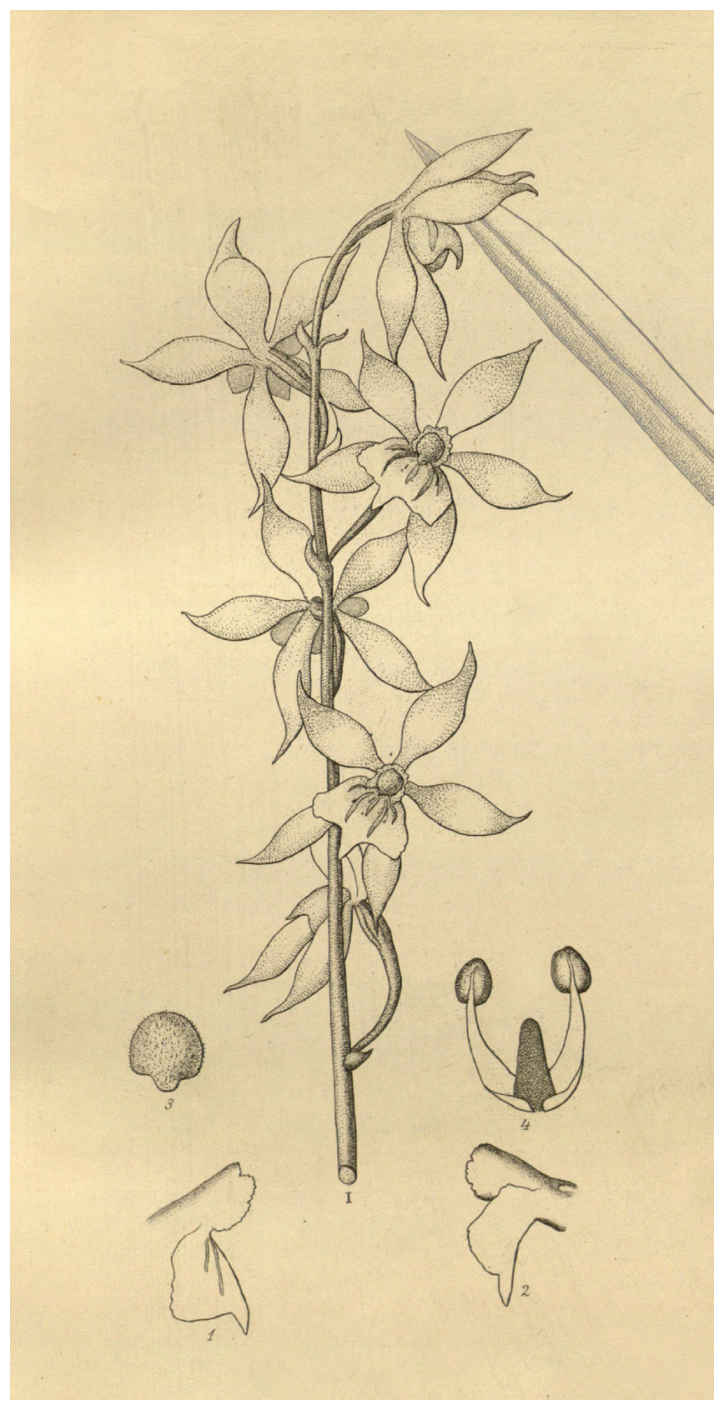

FiguRE 1. Illustration of Oliveriana egregia in Xenia Orchidacea, from Reichenbach 1883.

et al. 2014), and $O$. chocoana Szlach. \& Kolan., $O$. luerorum Szlach. \& Kolan., and O. pazii Szlach. \& Kolan. (Szlachetko \& Kolanowska 2014).

Including the new species described in this paper, and the 12 species in the World Checklist of Selected Plant Families (WCSP 2016), the number of described Oliveriana species adds up to 13. This number will no doubt shrink, however, because a couple of the species described in 2014 show more or less clear features that may place them in other genera. For example, Oliveriana puracensis has all the characteristics of a Caucaea Schltr., and O. guarinae is suspiciously similar to some members of Cyrtochilum Kunth. Several species are also morphologically very similar to each other and it seems possible that some will be considered as synonyms when more material becomes available for study. Examples are Oliveriana chocoana, O. pazii, and O. pseudoegregia, which all have very similar flowers and differ in details of the lip callus only, from what can be seen in the drawings of the type specimens (Szlachetko \& Kolanowska 2014, Szlachetko et al. 2014). In addition, Oliveriana ecudorensis is very similar to O. egregia and may prove conspecific when and if more material can be analyzed with regard to natural variation. Because very few preserved specimens exist, and few plants appear to be cultivated, we will probably have to wait for a while before these taxonomic question-marks can be straightened out with certainty.

\section{Taxonomic treatment}

Oliveriana hirtzii Dalström, sp. nov.

TYPE: Ecuador. Tungurahua: Rio Negro, $1500 \mathrm{~m}$, without collecting date, A. Hirtz 007 (holotype, SEL). Fig. 2.

Oliveriana hirtzii differs from all other species in the genus by the extremely elongated and narrow leaves in combination with a flower that has lateral sepals fused for about half of their length, a lip that is only indistinctly tri-lobed and with a fleshy triangular acute front-lobe, and a distinct column hood.

Epiphytic, caespitose herb with a semi-pendent habit. Pseudobulbs narrowly ovoid, almost linear, trifoliate, surrounded basally by 6-7 distichous sheaths, the uppermost foliaceous, $c a .6 .0 \times 0.4-0.5 \mathrm{~cm}$. Leaves narrow and grass-like, pendent, subpetiolate, conduplicate, linear, acuminate, 55.0-65.0 × 0.4-0.6 $\mathrm{cm}$. Inflorescence very slender and probably semipendent, 35-37 cm long on type specimen; bracts appressed, acute to acuminate, scale-like, 3-5 mm long; peduncle with ovary $12-15 \mathrm{~mm}$ long. Flower light green, semi-closed, possibly self-pollinating; dorsal sepal basally truncate, then narrowly ovate with a blunt apex, ca. $12 \times 3 \mathrm{~mm}$; lateral sepals truncate, fused for $c a .6 \mathrm{~mm}$, then obliquely narrowly ovate with a blunt acuminate apex, $c a .12 .0 \times 2.0-2.3 \mathrm{~mm}$; petals cuneately truncate, elongate triangular with an 


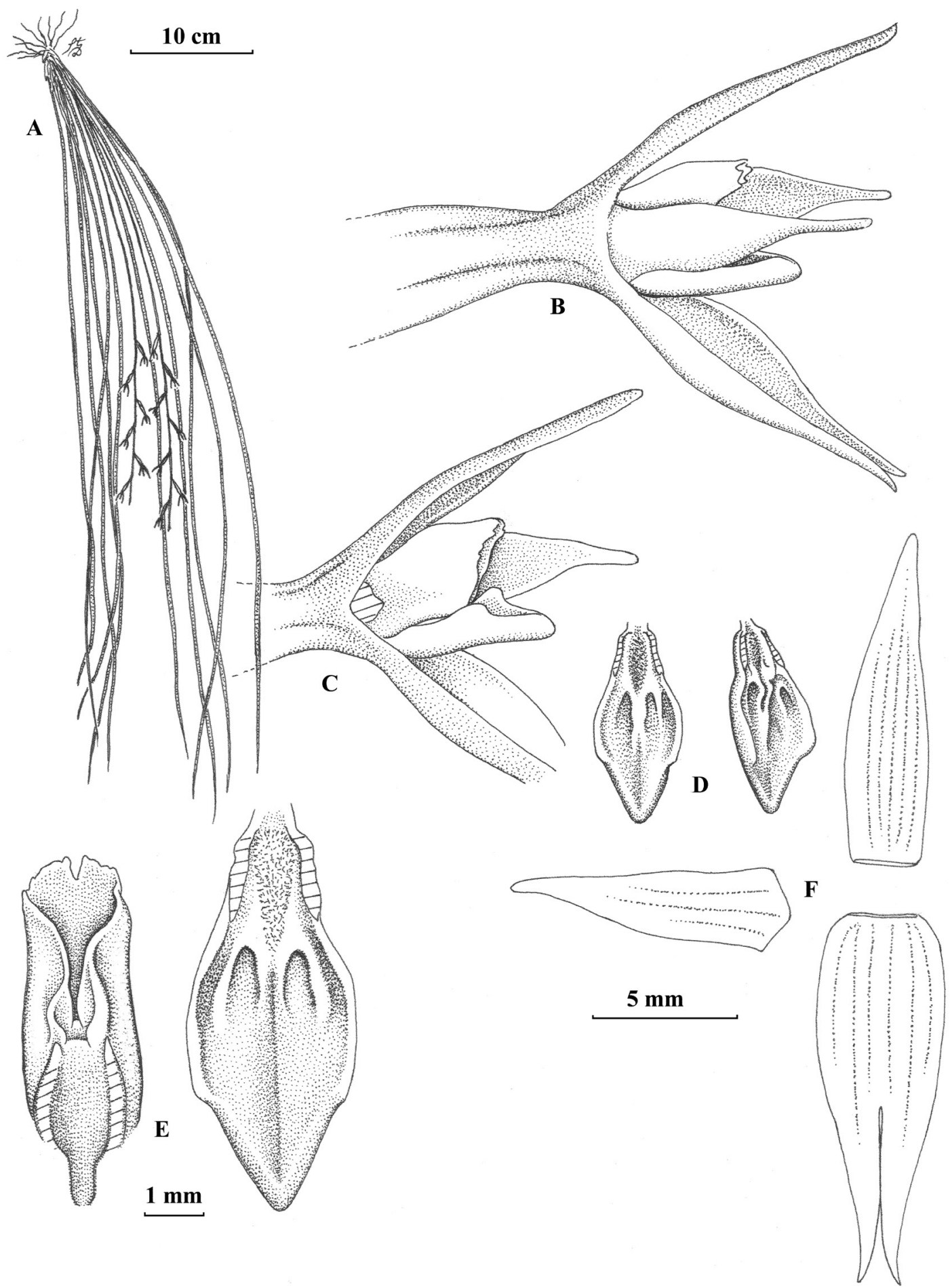

Figure 2. Oliveriana hirtzii. A. Plant habit. B. Flower, lateral view. C. Flower, lateral view with petal removed. D. Lip, dorsal and slightly angled views. E. Column, ventral view (left) and lip, dorsal view. F. Dissected flower. Drawn from holotype by Stig Dalström. 
indistinctly oblique, rounded apex, $c a .10 .0 \times 2.2 \mathrm{~mm}$; lip rigidly fused against the column along the lateral basal edges for $c a .1 .6 \mathrm{~mm}$, indistinctly trilobate with blunt side-lobes and a bluntly acute front-lobe, rather fleshy, ca. $6 \times 3 \mathrm{~mm}$; callus composed by a basal micro-pubescent cushion, then a fleshy, central, longitudinal short bi-lobed ridge, uniting apically into a single ridge, with a lateral, shorter and lower ridge on each side that create a shallow cavity at the base and against the central ridge; column short, straight and thick, with a well-developed dorsal hood, which obscures the stigmatic surface by the lateral flanks, 5.0-5.8 mm long, including the hood; anther cap not seen; pollinarium not seen.

Distribution: Known only from the type collection near where Río Verde joins the Río Pastaza in central Ecuador, in dense tropical forest at $c a .1500 \mathrm{~m}$ elevation.

Eponymy: This species is named in honor of Alejandro "Alex" Hirtz of Quito, Ecuador, who discovered this species very early in his amazing plant discovery career.

The only plant ever found of this unusual but rather unattractive species is a native of the lush, and in terms of biodiversity, extremely rich forests along the Río Pastaza in central Ecuador. No other material has been seen of this species despite several searches in the original area.

Because that all flowers of the type specimen have been successfully pollinated, which is unusual in Oncidiinae in general, it is speculated here that Oliveriana hirtzii may be self-pollinating. Many plant collectors, including this author, have visited the type area during many years without ever finding or reporting having seen this probably very difficult to spot orchid. Fortunately, large areas in this region are protected today thanks to a significant degree to the hard work by private individuals such as Lou Jost and his friends and supporters of the nearby town of Baños and elsewhere.
ACKNOWLEDGMENTS. I wish to thank Wesley Higgins for commenting on the manuscript, and two anonymous reviewers for their suggestions.

\section{LiteRATURE CITED}

Bentham, G. (1881). Notes on Orchideae. Botanical Journal of the Linnaean Society, 18, 281-360.

Chase, M. W. (2009). Oliveriana. In A. M. Pridgeon, P. J. Cribb, M. W. Chase \& F. H. Rasmussen (eds.). Genera Orchidacearum, vol. 5: Epidendroideae (306-308). Oxford: Oxford University Press.

Dodson, C. H. (1989). Oliveriana ecuadorensis. Icones Plantarum Tropicarum, ser. 2, 6, t. 558.

Dodson, C.H. \& Vásquez, R.. (1989). Oliveriana simulans. Icones Plantarum Tropicarum, ser. 2, 3, t. 270.

Dressler, R. L. \& Williams, N. H. (1970). The genus Systeloglossum. American Orchid Society Bulletin, 38(4), 323-329.

Garay, L. A. (1963). Oliveriana and its position in the Oncidieae. American Orchid Society Bulletin, 32(1), $18-24$.

Moore, H. E. \& Wood, C. E. (1965). Dates of publication of the journal Linnaea: further evidence. Journal of the Arnold Arboretum, 46, 68-73.

Pérez, A. F. (1969). El género Oliveriana. Orquideologia, $4(2), 85-89$.

Reichenbach. G. H. (1876). Orchideae Wallisianae novae. Linnaea, 41, 99-118.

Reichenbach, H. G. (1883). Xenia orchidacea. Beiträge zur Kenntniss der Orchideen. Dritter Band. F. A. Brockhaus, Leipzig.

Schweinfurth, C. (1949). A novel member of a popular genus. American Orchid Society Bulletin, 18, 578-580.

Szlachetko, D. L. \& Kolanowska, M. (2014). Three new species of Oliveriana (Orchidaceae-Oncidiinae) from Colombia. Phyton (Horn), 54(2), 197-204.

Szlachetko, D. L., Kolanowska, M. \& Olędrzyńska, N. (2014). Three new Oliveriana from Colombia. Annales Botanici Fennici, 51, 69-74.

WCSP (2016). World Checklist of Selected Plant Families. Facilitated by the Royal Botanic Gardens, Kew. Published on the Internet at http://apps.kew.org/wcsp/. Retrieved November 2016. 